\title{
Study on dioxan separation in the radioimmunoassay of human growth hormone, human chorionic gonadotrophin, adrenocorticotrophic hormone, and insulin
}

\author{
M. STAHL, J. GIRARD, J. B. BAUMANN, AND P. W. NARS \\ From the University Children's Hospital, Basel, Switzerland
}

SYNOPSIS The dioxan precipitation for separating free from antibody-bound hormone in a radioimmunoassay has been applied to human chorionic gonadotrophin (HCG), human growth hormone (HGH), adrenocorticotrophic hormone (ACTH), and insulin and compared with the charcoal-dextran system of separation. The dioxan separation depends on protein concentration. The behaviour of damaged labelled hormone is difficult to assess. Completeness of separation has to be tested in antigen excess. The optimum conditions must be carefully studied for each hormone.

\begin{abstract}
One of the main problems in radioimmunoassay is the separation of antibody bound from free labelled hormone. There are a great variety of techniques, each with its distinct advantages and disadvantages, based on electrophoresis, chromatoelectrophoresis, adsorption (eg, onto talc, charcoal, etc), solid phase antibody, immunoprecipitation, and chemical precipitation (Greenwood, 1967; Margoulies, 1968).

Thomas and Ferin (1968) have described the use of dioxan for selective precipitation of the antigenantibody complex in a radioimmunoassay for human chorionic gonadotrophin. The method appeared to be simple, quick, and inexpensive, and suitable for handling large series of samples. We therefore studied dioxan precipitation for separation of antibody bound and free HGH, HCG, ACTH, and insulin.
\end{abstract}

\section{Material and Methods}

\section{DILUENT}

For HGH, HCG, and insulin the diluent contained

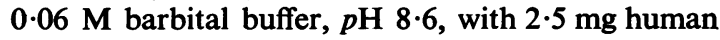
serum albumin per millilitre. For ACTH, $500 \mathrm{KIU}$ of Trasylol (Bayer) and $0.5 \%$ mercaptoethanol were added to the above diluent.

HORMONES FOR IODINATION AND STANDARD Human growth hormone was extracted from human pituitaries by the method of Raben (1959), including an additional purification step (Hunter, 1965), or following the procedure of Roos, Fevold, and Gemzell (1963). Human chorionic gonadotrophin was a highly purified preparation containing 13,200 IU/mg. Porcine insulin was a commercial preparation (Actrapid Novo). Synthetic $\alpha \mathrm{p}^{1-39}$ ACTH was obtained from Ciba.

IODINATION

Either 0.5 to $1.0 \mathrm{mC}{ }^{131}$ I or ${ }^{125}$ I (EIR Würenlingen, Switzerland) per $2 \cdot 5$ to $5.0 \mu \mathrm{g}$ of hormone was used for iodination by the chloramin-T-method of Greenwood, Hunter, and Glover (1963). Labelled HCG and HGH were purified on Sephadex G 75 . For ACTH and insulin a cellulose column was used (Yalow and Berson, 1960; Landon, Livanou, and Greenwood, 1967).

\section{ANTIBODIES}

Anti-HGH antibodies were raised in rabbits with Raben human growth hormone. Anti-HCG antibodies were obtained after immunizing rabbits with crude HCG (Pregnyl, Organon). Anti-ACTH antibodies were induced in rabbits by immunization with synthetic $\beta$ 1-24 corticotrophin. Anti-insulin antibodies were raised in guinea pigs by immunization with porcine insulin.

PAPAIN DIGESTION

Rabbit anti-HGH antiserum was digested according 
to Porter (1958). (Crystalline papain was obtained from $\mathrm{BDH}$.)

CHARCOAL-DEXTRAN METHOD OF SEPARATION The procedure outlined by Herbert (1968) was used. All incubation mixtures were in a final volume of $200 \mu \mathrm{l}$ containing at least $20 \%$ serum protein. Human growth hormone and insulin were separated with $1 \mathrm{ml}$ of a charcoal-dextran suspension in barbital buffer (8 $\mathrm{g} \%$ activated charcoal coated with $1 \mathrm{~g} \%$ dextran 150). For ACTH $200 \mu$ l of a charcoal-dextran suspension containing $1 \mathrm{~g} \%$ of charcoal coated with $0.5 \mathrm{~g} \%$ dextran 70 was used.

\section{PRECIPITATION WITH DIOXAN}

Dioxan (purest quality for chromatography, Riedelde Haen AG) was diluted with distilled water. Incubation mixtures were precipitated as outlined by Thomas and Ferin (1968): $800 \mu$ l of diluted dioxan was added to $200 \mu \mathrm{l}$ of incubation mixture. After mixing on a Vortex mixer and centrifuging at $\mathbf{3 0 0 0}$ rpm for 20 to 30 min the supernatant was discarded and the precipitate counted without further washing. The concentrations of dioxan indicated do not refer to the final concentration but to those present in the $800 \mu 1$ added.

\section{Results}

To find the optimum concentration of dioxan for precipitating selectively antibody-bound hormone्ष labelled HGH, HCG, ACTH, and insulin weê incubated in diluent alone or with an excess of the relevant antibody in a final volume of $200 \mu \mathrm{l}$. Afte incubation for two hours at room temperature the incubation mixtures were separated by adding $80 \bar{\theta}$. $\mu l$ of varying concentrations of dioxan (50-98\% The results are shown in Figure 1. Almost maximu而 precipitation of the $\mathrm{HCG}$ antibody complex wof obtained at a dioxan concentration of $74 \%$, but $15 \%$ of the free HCG is also precipitated. The corresponding figures for $\mathbf{H G H}$ are very similar, but highe् dioxan concentrations were required. Optimu艃 separation of $\mathrm{HGH}$ was achieved at a concentratiog of $78 \%$, when $6 \%$ of free and $65 \%$ of antibody-bouni hormone were precipitated. The insulin antibody complex is almost wholly precipitated $(82 \%)$ at dioxan concentration of $78 \%$ together with $9 \%$ free insulin. Ninety per cent of dioxan precipitateg $75 \%$ of the bound antibody and $12 \%$ of the free ACTH. Up to $85 \%$ of free HCG could be precipitate with $90 \%$ dioxan and up to $77 \%$ of $\mathrm{HGH}$ with $94 \%$ dioxan. In contrast, insulin and ACTH could b8 precipitated only up to $39 \%$ and $24 \%$ respectively. even at the highest concentration of dioxan used.

\section{INFLUENCE OF PROTEIN}

The influence of protein concentration on the chas coal-dextran separation of $\mathbf{H G H}$ is an unexplaine but well known phenomenon (Herbert, 196\%

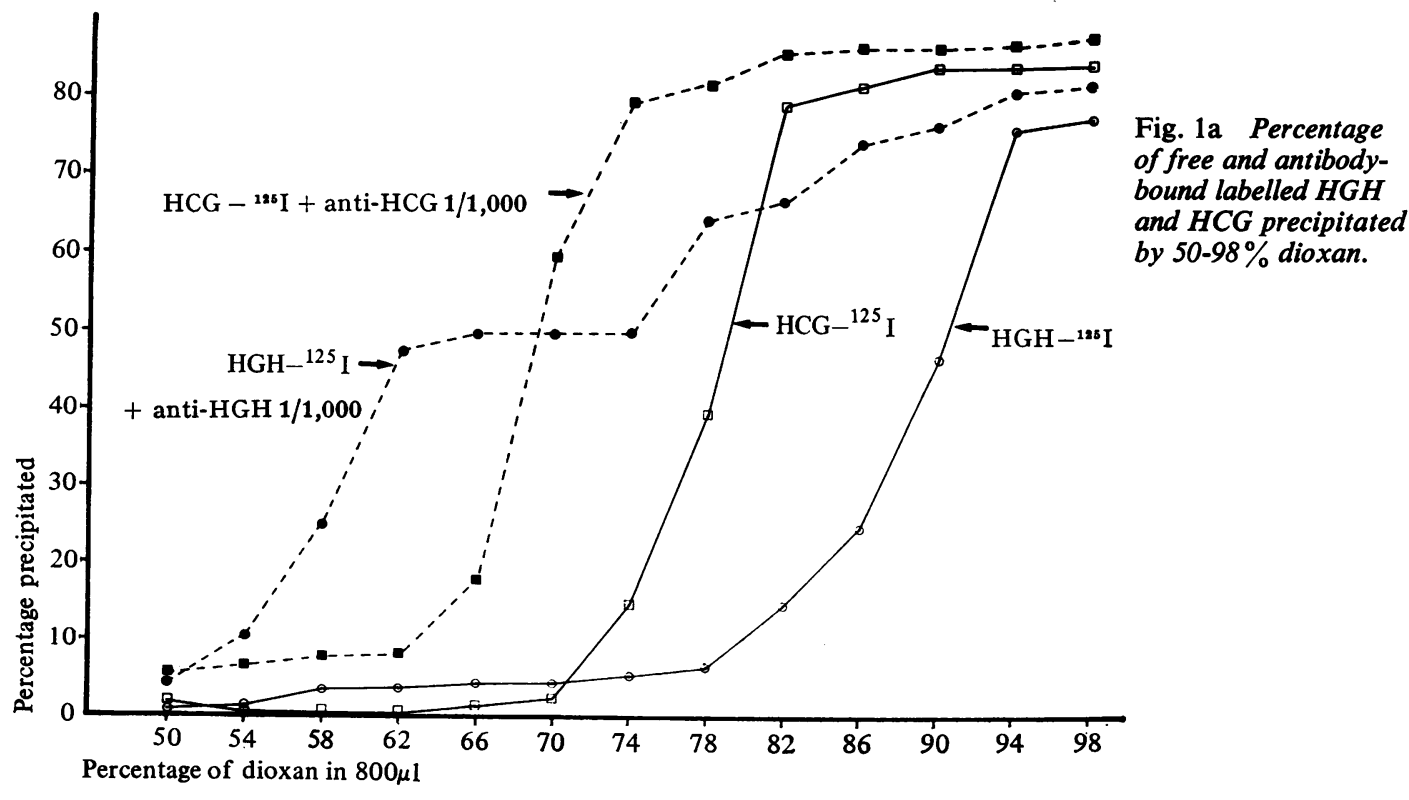

Fig. 1a Percentage antibodyand $H C G$ precipitated by $50-98 \%$ dioxan. 


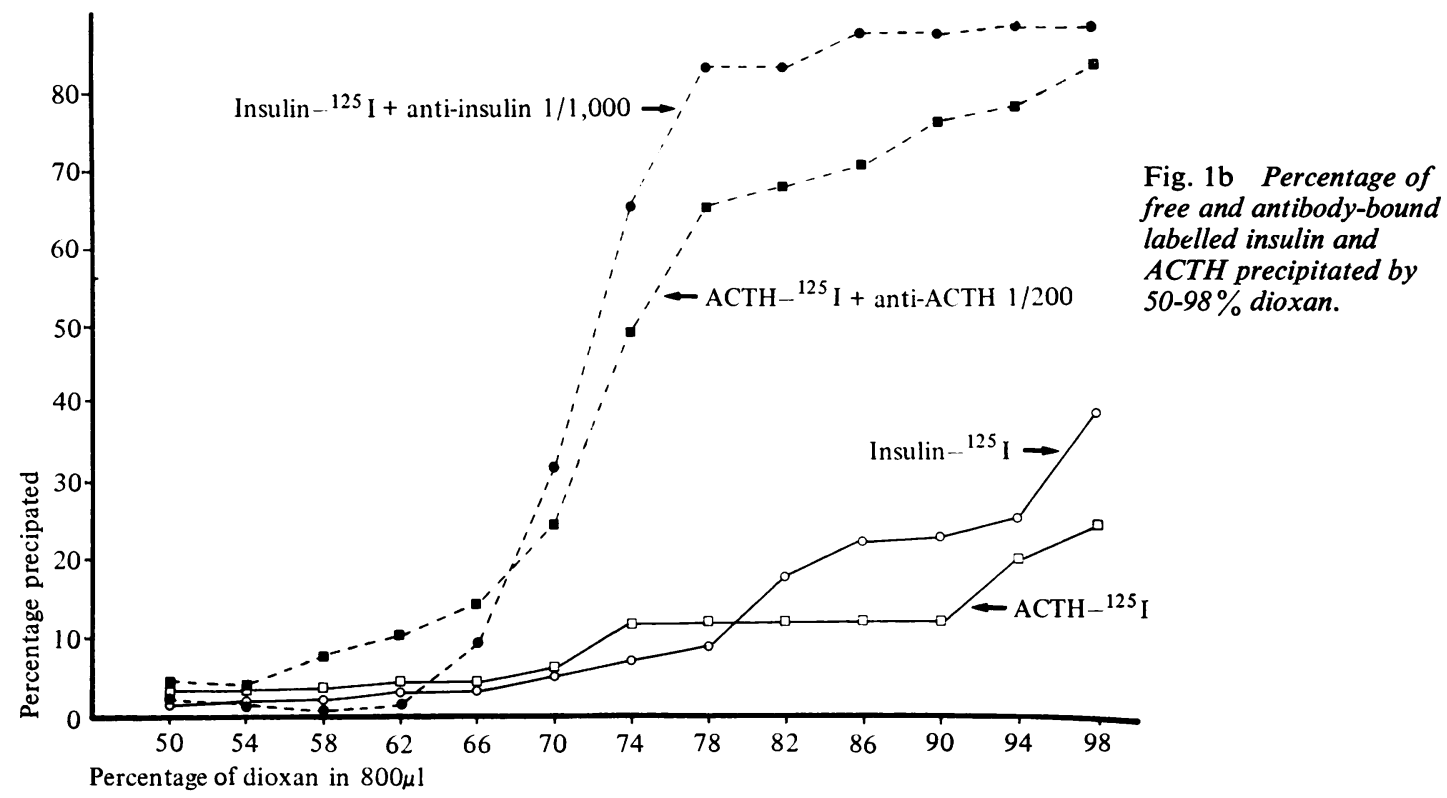

Girard, 1969). The effect of protein in the dioxan separation technique was therefore compared with that of charcoal-dextran (Fig. 2).

Insulin and HGH incubated in diluent alone or with an excess of antibody were separated with dioxan or charcoal-dextran after the addition of 0 to $40 \%$ of calf serum. The charcoal-dextran separation of insulin was fairly constant and almost independent of protein concentration over the range tested. Precipitation of the insulin antibody complex with dioxan, however, remained incomplete unless the serum concentration was raised to 20 to $40 \%$. 'Non-specific' precipitation of unbound insulin increased from 5 to $9 \%$ by raising the serum concentration from 0 to $40 \%$. For the separation of bound from free $\mathrm{HGH}$ an optimal concentration of $20 \%$ of serum protein must be included for both systems of separation.

In the above experiments serum protein was added immediately before separation. Apart from a slight increase in damage (see below) inclusion of protein during the entire incubation period did not affect the behaviour of $\mathrm{HGH}$ and ACTH in the dioxan system. However, insulin incubated with nonimmunoserum is precipitated to $34 \%$ by dioxan compared with $8 \%$ precipitation without the addition of serum protein. The level of damaged insulin incubated with or without serum is about $5 \%$ as judged from charcoal-dextran. A similar effect is seen with excess antibody. After incubation with addition- al serum protein, $84 \%$ of the radioactivity is precipitated by dioxan compared with $77 \%$ precipitation without additional serum protein. The 'nonspecific' precipitation of labelled HCG incubated with 'nonimmunoserum' is even more marked.

EFFECT OF DAMAGE ON LABELLED HORMONE Damaged hormone (in aggregated form or as fragments adsorbed to serum proteins) is excluded from dextran-coated charcoal. The behaviour of damaged hormone in the dioxan system has been investigated in the following series of experiments.

Labelled HGH and ACTH incubated without antiserum were separated with charcoal-dextran. The supernatant of the charcoal separation containing the damaged hormone was subsequently precipitated with the respective concentration of dioxan for separation of the bound and free hormone(seeabove). About $50 \%$ of the radioactivity in the charcoal supernatant was precipitated by dioxan. The experiment could not be repeated with insulin, because the level of damage was too low.

The charcoal-dextran system could not be applied to human chorionic gonadotrophin. In addition no batch of Whatman 3 MC paper suitable for chromatoelectrophoretic analysis of HCG could be found. Therefore only the dioxan system of separation could be employed. The percentage of free labelled HCG precipitated by $70 \%$ dioxan increased considerably by storing the label for a prolonged period 


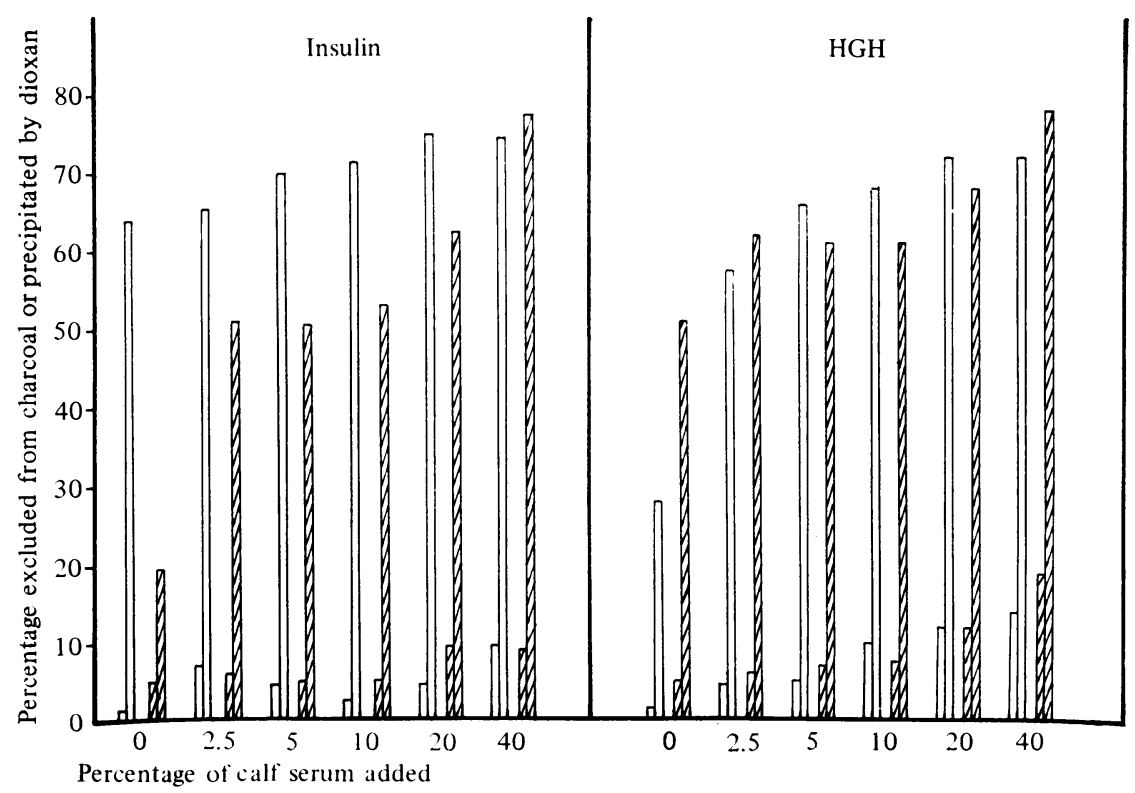

Charcoal dextran: open columns left without antiserum right with antiserum. Dioxan: hatched columns left without antiserum right with antiserum

Fig. 2 Influence of varying serum concentrations on separation.

of time to provide further indication of increased damage. Labelled HCG stored for six weeks or more and then incubated with excess antibody resulted in only $25 \%$ binding as judged from dioxan precipitation.

It appears, therefore, that some of the damaged hormone is precipitated by dioxan and leads to higher 'blanks' and apparently higher binding values, which may consequently decrease the slope of a standard curve. However, dioxan does not precipitate all of the damaged hormone and the hormones tested in the present study differed somewhat one from another. Thus the behaviour of damaged hormone in the dioxan system could not be completely elucidated.

\section{ANTISERUM TITRATION}

In order to compare the charcoal-dextran separation with dioxan precipitation doubling dilutions of antiinsulin antiserum were set up in duplicate. After correction of the serum concentrations by adding calf serum, each of the duplicate series was separated with either charcoal-dextran or dioxan respectively. In excess antibody (ie, antiserum dilutions $1 / 2,000$ $1 / 32,000$ ) both separation systems gave similar results, $60-65 \%$ of labelled insulin appearing in the 'bound' fraction. In the region of excess antigen, where the assay is performed, an impressive difference in apparent binding of the label was observed. At an antiserum dilution of $1 / 256,000$, dioxan precipitated $25 \%$ of the radioactivity, whereas $50 \%$ of the labelled hormone was excluded from dextrans coated charcoal. The percentage damage to labelle insulin as assessed with charcoal and chromato electrophoresis was well below $10 \%$.

To elucidate the possible reason for the discrepanc $\overrightarrow{5}$ between the charcoal dextran and dioxan systems $o B$ separation in excess of antigen, the following experi? ment with an anti-HGH antiserum was performed.

Antiserum titration with papain-digested antiserum Antiserum titration curves were set up in duplicate both before and after digestion of anti-HGH antiserum with papain. The serial dilutions of com윽 plete and papain-digested antisera were separated with either dioxan or charcoal-dextran (Fig. 3)? Some loss of antiserum due to the papain digestion step is obvious from the difference between complete and digested antiserum dilution curves separated with charcoal-dextran. Dioxan at a concentration of $74 \%$ precipitated the untreated antiserum completel and gave somewhat higher bindings than charcoal $\omega$ dextran over the range of antiserum dilutions tested?

After papain digestion, however, the binding foun $\&$ with charcoal-dextran was considerably higher thard that found with dioxan precipitation. Judged by the charcoal separation, about $40 \%$ of labelled hormone bound to digested antiserum is not precipitate by $74 \%$ of dioxan at the dilution of antiserum tested? The explanation for this finding is given in Fig. 4 Q 


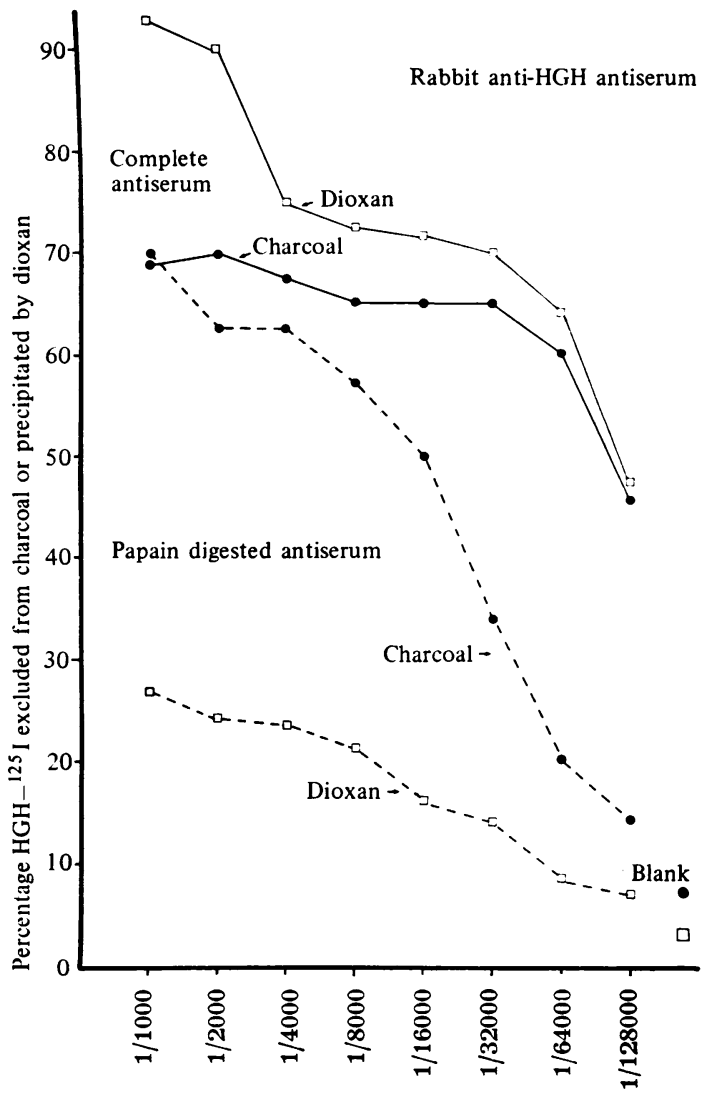

Fig. 3 Anti-HGH antiserum titration. Comparison between charcoal-dextran and dioxan separation before and after papain digestion of antibody. Complete antibody $\square \longrightarrow \square$ dioxan $(74 \%)-\longrightarrow$ charcoaldextran

Papain-digested antibody $\square---\square$ dioxan $(74 \%)---1$ charcoal-dextran.

Fig. 4 Percentage $\mathrm{HGH}^{-125}$ I precipitated by $54-98 \%$ dioxan. $\bigcirc-\bigcirc$ free $\mathrm{HGH}^{-125} \mathrm{I}$ bound to papain-digested antibody $(1 / 4,000)$ $H G H_{-125}$ I bound to complete antibody $(1 / 16,000)$.

Antiserum dilution

Fig. 3.

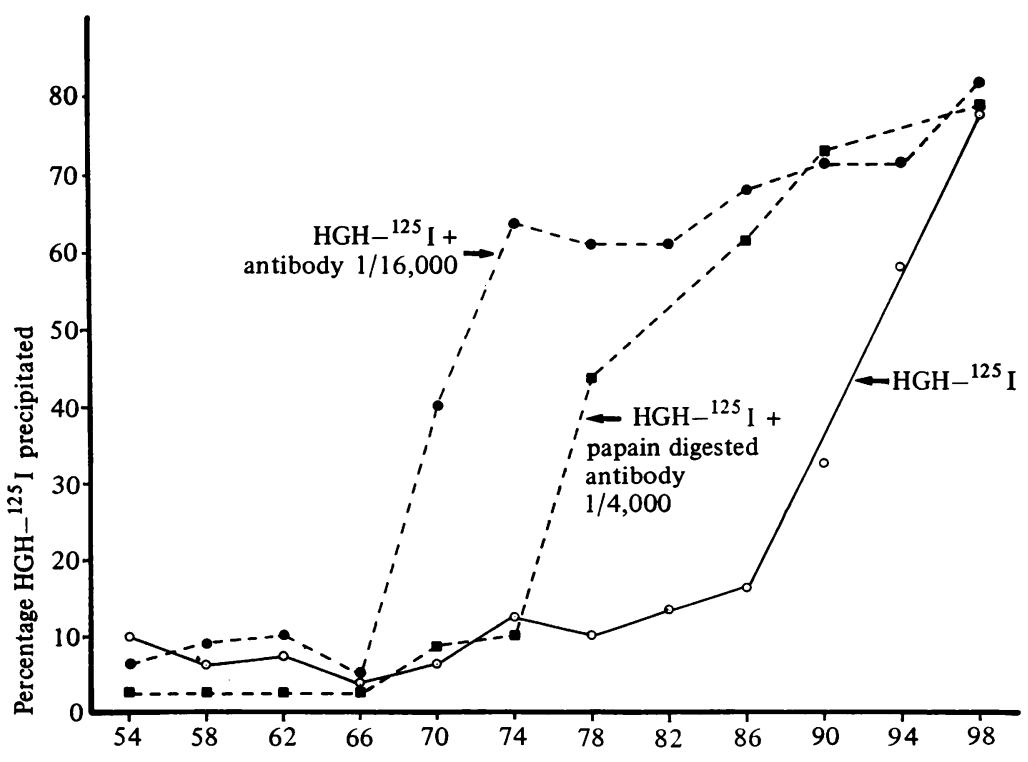

Percentage of dioxan in $800 \mu 1$

Fig. 4. 


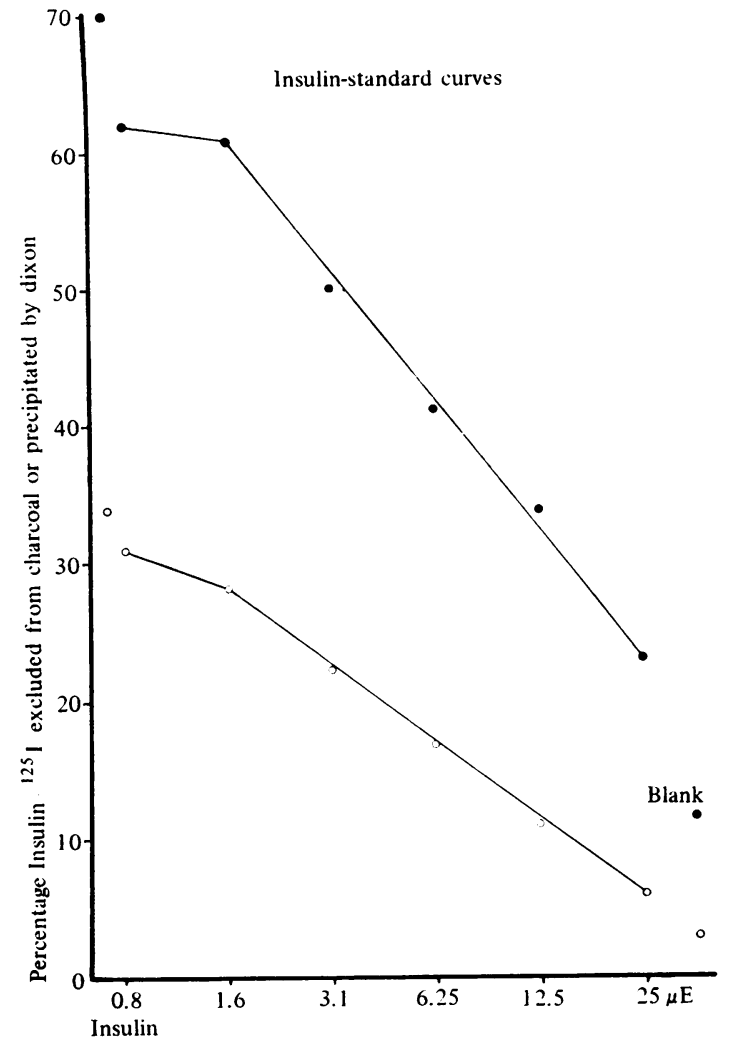

Fig. 5a Insulin standard curves. Comparison between charcoal-dextran (- $)$ and dioxan ( $78 \%)$ $(\bigcirc-O)$ separation (Anti-insulin antiserum 1/125,000).

which shows the different concentrations of dioxan required to precipitate $\mathrm{HGH}$ bound to complete antibody, papain-digested antibody, and free human growth hormone. The respective concentrations of dioxan for nearly complete precipitation are $70 \%$ for complete antibody, $86 \%$ for digested antibody, and, as shown before, $94 \%$ for free human growth hormone.

\section{Standard Curves}

From the experiments described above it could be anticipated that under the conditions of an assay, ie, in slight excess of antigen, dioxan would not precipitate all of the antibody-bound hormone and could therefore lead to erroneous results.

Calibration curves for insulin and HGH were set up in duplicate. Each series was separated with either charcoal-dextran or dioxan. From the results in Fig. 5 it is evident that both antibody-bound

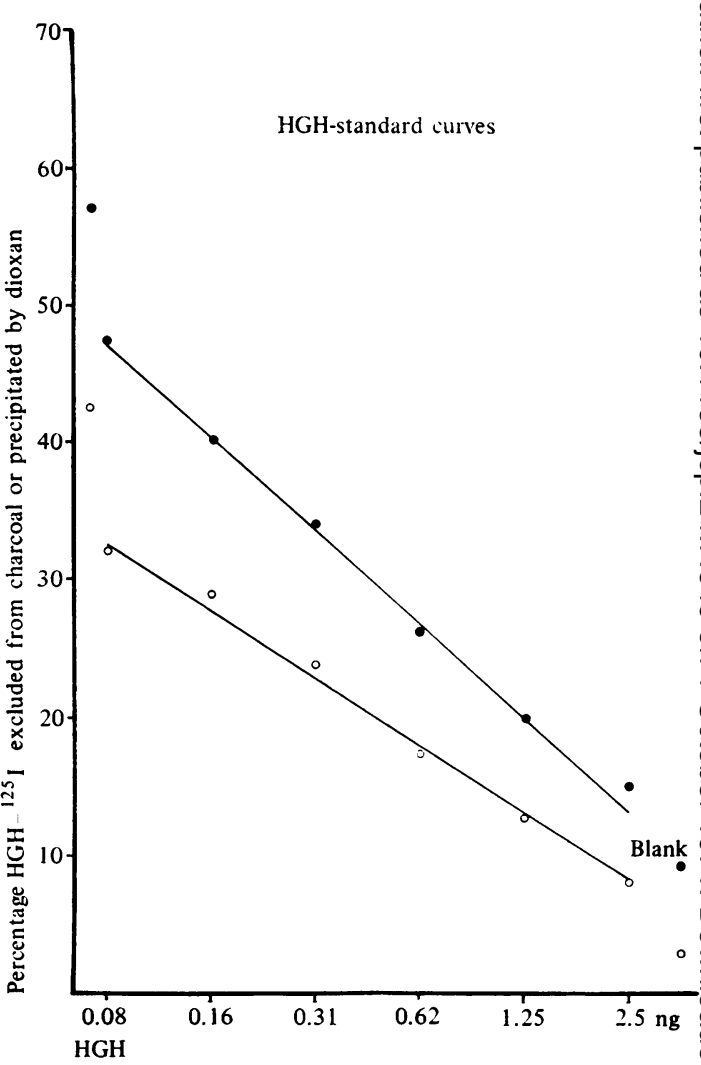

Fig. 5b HGH standard curves. Comparison between charcoal-dextran $\longrightarrow$ and dioxan $(78 \%) \bigcirc-\bigcirc$ separation (Anti-HGH antiserum 1/200,00).

insulin and HGH are not completely precipitated by dioxan. The charcoal separation gives higher binding values throughout. The negative controls without antiserum are also somewhat higher in the charcoas separation compared with those of dioxan. The insulin-anti-insulin system gives considerably more divergent results than the HGH system.

\section{Discussion}

Some of the factors when deciding upon the suit ability of a separation system are (Hunter and ${ }^{\omega}$ Ganguli, 1970): (1) completeness of separation of bound from free hormone; (2) volume of incubate which can be handled; (3) effect of variation in protein concentration; (4) behaviour of the damaged label; (5) speed of separation; (6) cost of materials and (7) the general application of the technique.

None of the separation systems currently used fulfil all of the requirements listed above. The dioxano 
system of separation is no exception in this respect but it shares certain advantages with other systems of separation. (1) The entire incubation mixture can be used for separation. (2) Large series of samples can easily be handled. (3) The manipulations involved do not require any special skill. (4) The separation is quick and the material inexpensive.

As discussed by Thomas, Nash, and Ferin (1969), there are, however, some important problems involved, which have to be carefully controlled, and some of their findings can probably be explained by the results obtained in the present study. Completeness of separation is important. From the experiments performed it is evident that a complete separation is obtained with excess antibody. In slight excess of antigen, however, a considerable discrepancy between the dioxan system and the charcoal system was observed. In contrast to the charcoal system of separation, the dioxan precipitation requires a marked excess of antibody to obtain a $50 \%$ binding of labelled hormone. The resulting sensitivity of the assay would therefore be reduced in the dioxan system. This is explained by the conclusions which can be drawn from the experiments performed. The concentration of dioxan required for precipitation appears to be proportional to the size of the molecule or molecular complex. Increasing concentrations of dioxan are required for precipitation as the molecular size decreases. This is obvious from Fig. 1, which shows that the large molecules of free HGH and HCG can be precipitated to a great extent by dioxan whereas only small amounts of the low molecular weight hormones such as insulin and ACTH are precipitated, even at the highest concentration of dioxan used.

Furthermore in a multivalent antigen-antibody system excess antibody may lead to the formation of large molecular size antigen-antibody complexes. As shown in Fig. 1, a relatively low concentration of dioxan is required to precipitate such large complexes. In excess antigen, however, the formation of large complexes is very much less likely to occur. As shown in the experiments with papain-digested antibodies, concentration of dioxan sufficient to precipitate the large complexes leave the monovalent antigen-antibody molecules in solution.

Theoretically the problem could therefore be overcome by digesting antibodies before assessing the optimum concentration of dioxan required for complete separation. As an alternative, using undigested antibody, the dioxan concentration should not be tested in excess antibody but in the working range of the assay, ie, in a slight excess of antigen. The papain digested, ie, monovalent antibodyantigen molecules, must however be completely precipitated at a dioxan concentration which leaves the free hormone in solution. As shown in Fig. 4, these conditions can be found for human growth hormone. Similarly in the insulin and ACTH system the free hormone is only partly precipitated at very high dioxan concentrations and a separation between free hormone and hormone bound monovalently (ie, to papain-digested antibody) should be possible. Free HCG, however, is precipitated to a great extent at a dioxan concentration only slightly above that required for complete precipitation of the multivalent large antigen-antibody complex. A separation between free HCG and HCG bound to papain-digested antibody is probably impossible.

A further important problem is the effect of damaged hormone. From our observations the effect of damage cannot be reasonably controlled in the dioxan system.

The dioxan system of separation can be applied to a series of different hormones. The possible incompleteness of separation, the effect of serum protein, and the unpredictable behaviour of damaged hormone requires a very careful comparison with other systems of separation.

\section{References}

Girard, J. (1969). In Protein and Polypeptide Hormones, edited by M. Margoulies, pt 3, pp. 638-639. Excerpta Medica Foundation, Amsterdam.

Greenwood, F. C. (1967). Immunological procedures in the assay of protein hormones. In Modern Trends in Endocrinology, edited by H. Gardner-Hill, vol. 3, pp. 288-335. Butterworth, London.

Greenwood, F. C., Hunter, W. M., and Glover, J. S. (1963). The preparation of ${ }^{131}$ I-labelled human growth hormone of high specific radioactivity. Biochem. J., 89, 114-123.

Herbert, V. (1968). Coated charcoal separation of free labelled hormone from hormone bound to antibody. In Protein and Polypeptide Hormones, edited by M. Margoulies, pt 1, pp. 55-60. Excerpta Medica Foundation, Amsterdam.

Hunter, W. M. (1965). Homogeneity studies on human growth hormone. Biochem. J., 97, 199-208.

Hunter, W. M., and Ganguli, P. C. (1970). The separation of antibody bound from free antigen. In Radioimmunoassay Methods: European Workshop, 15-17 Sept., Edinburgh.

Landon, J., Livanou, T., and Greenwood, F. C. (1967). The preparation and immunological properties of ${ }^{131}$ I-labelled adrenocorticotrophin. Biochem. J., 105, 1075-1083.

Margoulies, M., Editor (1968). Labelling-separation of free labelled hormone from antibody-bound hormone. In Protein and Polypeptide Hormones, pt 1, pp. 36-61. Excerpta Medica Foundation, Amsterdam.

Porter, R. R. (1958). Separation and isolation of fractions of rabbit gammaglobulin containing the antibody and antigenic combining sites. Nature (Lond.), 182, 670-671.

Raben, M. S. (1959). Human growth hormone. Recent Progr. Hormone Res., 15, 302-303.

Roos, P., Fevold, H. R., and Gemzell, C. A. (1963). Preparation of human growth hormone by gel filtration. Biochem. biophys. Acta (Amst.), 74, 525-531.

Thomas, K., and Ferin, J. (1968). A new rapid radioimmunoassay for HCG (LH, ICSH) in plasma using dioxan. J. clin. Endocr., 28, 1667-1670.

Thomas, K., Nash, D., and Ferin, J. (1969). Chemical precipitation techniques for the radioimmunologic quantitation of gonadotrophins with special reference to the organic solvent dioxane. Acta endocr. (Kbh.), 63, Suppl., 142, 279-299.

Yalow, R. S., and Berson, S. A. (1960). Immunoassay of endogenous plasma insulin in man. J. clin. Invest., 39, 1157-1175. 